\title{
Passando o bastão
}

Com este fascículo 13.3, Estudos de Psicologia (Natal) conclui seu primeiro ano como periódico exclusivamente eletrônico, ao mesmo tempo em que vê mudar o comando interno das operações; eu finalizo minha atuação como editor, seguem na função Isabel Fernandes de Oliveira e Symone Fernandes de Melo. Isabel integra com competência nossa equipe editorial há vários anos e certamente saberá enfrentar os desafios que virão; Symone já fez parte da Comissão Editorial e, mais recentemente, aprofundou a experiência como editora associada. Sucesso à nova equipe!

Ser editor de um periódico generalista em Psicologia é uma experiência extremamente enriquecedora e, ao mesmo tempo, repleta de desafios e incertezas. Aprende-se muito sobre a área de conhecimento, sobre diferentes estratégias de se construir conhecimento, sobre os múltiplos pontos de vista relativos a uma mesma questão, sobre maneiras diversas de realizar uma comunicação escrita... No entanto, também se é confrontado com a necessidade de tomar decisões para as quais nossa formação acadêmica não nos prepara. Decisões às vezes mais fáceis, ainda que "duras"; outras vezes muito difíceis, porque envolvendo sutilezas teórico-metodológicas, áreas de atuação ainda pouco conhecidas, alinhamentos políticos, ideológicos e epistemológicos de autores, consultores e/ou integrantes da Comissão Editorial ou Conselho Científico.

Essa tarefa só me foi possível por que pude contar com várias ajudas; por isso, tenho muito a agradecer, desde que o bastão me foi passado por meu antecessor, Oswaldo Yamamoto, em abril de 2003. Em primeiro lugar, ao próprio Oswaldo, por nos ter liderado - a partir do "quase nada" com que começamos, em 1996 - na construção de um periódico de distinguida qualidade, reconhecida pelos níveis mais elevados reiteradamente conquistados na classificação nacional de periódicos científicos de Psicologia (depois de vários "Nacional - A", somos agora “A-2”). Registro também meus agradecimentos aos editores adjuntos que assumiram a editoria comigo - Isabel Fernandes de Oliveira e Márcio J. Capriglione -, e muito contribuíram para a boa qualidade dos trabalhos realizados. Mais recentemente, Jorge Falcão integrou a gestão da editoria associada, ao lado de Isabel e Symone, mas os rumos que definiu para sua carreira acadêmica não lhe permitiram seguir na equipe.

Cabe também agradecer a dois importantes apoios externos. Nosso periódico tem logrado obter o apoio financeiro do Programa Editorial do CNPq - mais recentemente, com participação da CAPES - que tem sido fundamental para fazer frente às muitas despesas envolvidas na manutenção de um periódico científico com o alcance e a qualidade do nosso. Igualmente importante agora vital, considerando a existência exclusivamente eletrônica - tem sido o apoio da SciELO (Scientific Electronic Library Online) que, desde 2001, "hospeda" (http://www.scielo.br/ epsic) o acervo de sumários (em português e inglês), resumos/ abstracts e textos integrais dos artigos publicados por Estudos de Psicologia (Natal).

Aos colegas do Conselho Científico e, principalmente, aos integrantes da Comissão Editorial, registro aqui minha gratidão pelo auxílio prestado. Enfrentando as mesmas conhecidas dificuldades institucionais para a realização das tarefas editoriais, souberam contribuir para decisões mais acertadas, bem como correções de rumo sempre que necessárias.

Meus agradecimentos se estendem a nossos leitores, importantes agentes do sucesso desta Revista; aos autores, cuja confiança e opção por nossa Revista são parte essencial do produto; e aos colegas avaliadores dos manuscritos submetidos, garantia indispensável da qualidade dos trabalhos publicados.

Durante os anos em que estive à frente da editoria, vi as comunicações "em papel" (cartas, manuscritos, fichas de avaliação, envelopes, selos, etc.) serem gradualmente substituídas por seus equivalentes em formato eletrônico, o que implicou lidar com as conseqüentes adaptações tecnológicas e culturais - nossas, de autores e de consultores. Pouco tempo depois, passamos a utilizar o SEER (Sistema Eletrônico de Editoração de Revistas) no gerenciamento editorial, que acrescentou radical alteração das rotinas internas e externas. Em ambos os casos, fui assistido pela equipe de apoio editorial, um elemento de crescente importância para o funcionamento da Revista nestes últimos anos. Em editorial anterior já tive oportunidade de agradecer à secretária do Departamento de Psicologia da UFRN, Régina G. Melo, pela relevante contribuição prestada à Revista; nesta oportunidade, gostaria de me estender às pessoas envolvidas na equipe de apoio editorial propriamente dito.

As equipes do início desse período eram formadas por estudantes de graduação do curso de Psicologia, que atuavam em regime de tempo parcial, desdobrando-se para dar conta das várias frentes de ação. As alunas que atuavam como apoio editorial quando iniciei como editor eram Ana Ludmila F. Costa, Candida M. B. Dantas e Murielle A. Gomes, a quem agradeço pela "passagem do serviço". Com a saída das duas primeiras, vieram Rebeca S. Araújo e Thiago F. Pinheiro, que ajudaram a disciplinar o uso das rotinas de correio eletrônico. Ao começarmos a ensaiar a implantação do SEER, estavam Ana Paula S. Souza e Lara S. Dantas e, depois delas, Juliana T. C. Reis 
e novamente Thiago F. Pinheiro. Nessa época pudemos passar a contar com uma secretária com perfil profissional adequado à função, graças ao inestimável apoio financeiro proporcionado pela UFRN.

Concluíamos a implantação do SEER, com supervisão técnica de informática de Frederico A. F. Silveira e projeto gráfico da "página" da Revista de Louise Elali. Assumiu a secretaria Ana Ludmila F. Costa, que já havia sido parte do apoio editorial e se afastara para fazer um mestrado relacionado ao tema da avaliação de periódicos. Com a gradual eliminação das muitas tarefas da “era do papel” na Revista, pudemos prescindir do apoio prestado pelos estudantes de graduação. Mais recentemente, com a saída de Ana Ludmila, tivemos mais duas secretárias: Keyla M. O. Amorim, que não pode permanecer no cargo por ter se tornado bolsista de mestrado (com temática de estudo também na área); e Soraya Souza de Andrade, ex-bolsista de IC e mestre em Psicologia, que continua no cargo atualmente. A todas essas pessoas, meu muito obrigado pela colaboração!

Só quem já viveu a editoria de um periódico científico na realidade de nossas instituições públicas de ensino superior saberá valorizar a importância de uma secretária que: sabe usar o computador (não só editor de texto, planilha eletrônica, motores de busca na internet e programa de e-mail, mas também o manejo do SEER), tem redação própria, lê em inglês e espanhol, tem boas habilidades interpessoais (o que às vezes é imprescindível), entende e valoriza o sigilo inerente ao processo de avaliação editorial double blind review, não entende totalmente mas convive bem com a imensa variedade de temas dos manuscritos, assessora os editores com lembretes sobre tarefas e prazos a cumprir, e só não prepara o cafezinho porque ainda não tivemos dinheiro para a máquina de espresso.

Aliadas às mudanças nos periódicos científicos de Psicologia em âmbito nacional, modificações nessa área no cenário local fazem supor que o profissionalismo na produção e divulgação do conhecimento científico irá se desenvolver na UFRN. Desde que iniciamos a pós-graduação, em meados dos anos 1990, insistimos em preparar nossos alunos em pesquisa bibliográfica e comunicação científica (esforço semelhante, em nível mais elementar, também vem sendo feito na graduação). Nossos grupos de pesquisa têm tido cada vez mais inserção nacional, como atesta, por exemplo, a maciça participação de nosso corpo docente nos simpósios da ANPEPP. Além disso, a "mera” existência de Estudos de Psicologia (Natal) gera repercussões, tanto local como nacionalmente.

Estudos de Psicologia atravessa um momento de ajuste em sua política editorial, com vistas a melhor servir à comunidade acadêmica e científica de Psicologia em nosso país e se adequar aos novos tempos que se apresentam aos periódicos científicos da área. Adequar-se às condições não é novidade para nossa Revista. Em sua relativamente curta existência, foram várias as mudanças realizadas; todas bem sucedidas, a julgar pelo fato de ela ter se mantido nos níveis mais altos de classificação desde o início do processo de avaliação de periódicos científicos da área. Estamos buscando estabelecer uma política editorial mais focalizada, visando agilizar o processo de divulgação do conhecimento produzido; nesse ínterim, todos os artigos que estão em trâmite serão avaliados e, caso tenham mérito, serão publicados.

$\mathrm{Na}$ nominata de consultores anexa listamos os 173 pareceristas que colaboraram conosco no período de agosto de 2007 a julho de 2008, prestando inestimável contribuição para o bom funcionamento de um empreendimento editorial científico baseado no princípio da avaliação cega pelos pares.

Os artigos que compõem este fascículo cobrem um leque variado de temas, e foram produzidos por pesquisadores de instituições distintas, de vários estados da federação e do exterior.

A você, leitor, obrigado pelo apoio, e bom proveito.

José Q. Pinheiro

Editor

março / 2009 